\title{
Sustainable tourism and land resources for non-motorised mobility
}

\author{
E. Chiaf \& M. Pezzagno \\ Department of Civil Architectural Environmental and Land Planning \\ Engineering, Brescia University, Italy
}

\begin{abstract}
In Italy, the non-motorised vehicles network in extra-urban areas is fragmented. In recent years the growing demand for non-motorised mobility for recreational and tourism purposes has implied long distance itineraries planned along natural, historical and cultural resource systems. Non-motorised mobility could be a way to promote tourism rediscovering the territory. In fact it is promoting an interest for the renewal of dismissed railway tracks, military paths, banks and towpaths of rivers and channels, old linear infrastructures that are the safeguard of a territory. Such linearity should become the physical element to favour the use of the territory in a sustainable way through non-motorised mobility. A greenway network, that is able to put people in contact with the territorial resources also connecting them with the historical centres and with the small tourist areas, implies a planning approach that takes care of the new social needs of the people in outdoor recreation and tourism.
\end{abstract}

Keywords: greenway, land resources, non-motorised mobility, towpaths, linear infrastructures.

\section{Introduction}

In Italy the network of routes for non-motorised mobility outside urban areas mainly consists of mountain paths, military roads and tracks, mule tracks, nature routes, farm holiday walks, etc., and is largely disjointed.

In recent years the increasing demand for non-motorised mobility for tourism and recreation has encouraged more and more planning of routes crossing entire areas, linking environmental, historical and cultural places of interest.

Research has been aimed at defining a methodology for understanding, evaluating and exploiting both the linear aspects as well as the various natural 
and/or man-made morphological systems involved (river banks, canals and streams, disused railway lines, particularly along lakesides and seashores; sheep tracks; military roads; etc.) which might provide the structural element to adapt the system for slow (non motorised) mobility in the areas concerned, as well as the tourism potential deriving from the recovery of historic routes from the classic age (the system of Roman roads might be a particularly significant case), from the Middle Ages (just spare a thought for the pilgrim routes, the "Romei" leading to Rome, Santiago de Compostela, Jerusalem, etc.) and more still.

\section{Methodology}

The Cofin 2003 research of national interest entitled: "Land resources for nonmotorised mobility: interdisciplinary, project-oriented, comparison and experimentation" (National Coordinator: Prof. R. Busi, Brescia University) funded by MIUR (The Ministry for Education, University and Research) was highly interdisciplinary in the topics covered and had the strategic aim of setting up a methodological procedure to identify the criteria for:

- analysing local resources available for non-motorised mobility (both in terms of surface terrain able to accommodate the routes as well as accessible and perceptible environments and landscapes);

- assessing opportunities and also restrictions of a legal nature;

- planning route systems also bearing land ownership in mind.

The main aim of the research was therefore to provide that interdisciplinary approach to planning which, starting form the individual local components, is to analyse not only specific issues, the scope of protection, as well as natural and human resources, but also potential scale synergy induced by implementing morphological linear features as networks for non motorised mobility.

Implementing infrastructures on the scale of a local area, if correctly integrated with planning for non motorised mobility on an urban planning scale, has a strategic role both by contributing to change in the form of transport, encouraging the non motorised option, as well as by promoting new kinds of tourism aimed at exploiting the natural, historical and cultural resources available within an area. In recent years Italy too has seen an enormous increase in active tourism (rambling, biking tours, "alternative" skiing, snowshoeing, etc.), involving an ever-increasing number of locally-employed personnel, leading to the requirement of more and more frequent comparison between the many and diverse initiatives under way, as the means of implementing policies for sustainable development.

The wide range of experiences taking place in Italy, in the absence of a comprehensive methodological approach, first and foremost of the "urban planning/transport" kind, risks losing both the scale synergies as well as the induced potential deriving from the reconstruction and qualification of physical connections between significant point and linear elements which exist locally without, on the other hand, succeeding in providing completely sufficient answers to the increasing demand for non motorised mobility for recreation and tourism which requires, besides an extensive range of choice in the infrastructure 
(different routes, more or less complex, more or less equipped), also a high degree of specialisation in the services offered (reception structures, possibility of luggage transport, information maps, high quality bike hire, etc.) along the itinerary.

A system of routes devoted to "smooth" and non motorised travelling, able to connect the population with the resources which the area can offer (natural, agricultural, landscape, historical and cultural resources) and with the "living centres" of urban settlements both in towns and small urban centres, implies studying and planning both the infrastructures as well as the elements which go to make up the system, and at different levels for the area concerned (national, regional, provincial, local). What is still lacking in Italy are considerations of a theoretical, methodological kind, aimed at identifying criteria for planning, design and management for an integrated system of routes for non motorised mobility, able to provide answers to the increasing demand for non systematic mobility also of the receptive tourism kind. Debate within the research group has first and foremost focused on two fundamental aspects:

1. The vocabulary used has different meanings in the various disciplines even when referring to simple terms such as "route".

Each Research Unit (RU), through the abilities and knowledge it possesses, assigns a different meaning to terms which most frequently occur when dealing with the themes of non motorised mobility, linked to the concept of rediscovering and exploiting the resources of an area for reasons of tourism and economy. The first effort made by the work group was to set up a common vocabulary, shared by each RU, as a starting point and a cue for developing some interdisciplinary considerations and reflections for the purpose of solving the problems which arose within the scientific debate. The choice fell on few terms (greenway, infrastructure, service structures, real estate, services, etc.) whose common definition was held to be inevitable.

2. Public law stands as a fundamental and transversal subject with respect to the different themes; the presence of a jurist specialised in this subject is therefore indispensable for identifying problems and legislative loopholes which may jeopardise a priori the completion of an itinerary.

The analysis which was carried out has highlighted how the motivations, logics and as a consequence the policy decisions which lead to the creation of a network for non motorised mobility for an area can profoundly differ when observed from a town planning/transport or economy point of view.

Networks for non motorised mobility hold a strategic role in the perspective of an improvement in the living conditions in urban areas and of promoting sustainable mobility, both at urban and local level.

The topic of "smooth mobility" contributes in encouraging the development of new forms of tourism aimed at rediscovering the natural, historical and cultural resources available within the area.

An approach to the study of routes for non motorised mobility from a tourism point of view has focused attention on new problems of a strongly interdisciplinary nature: from strategic choices on the subject of tourism costs/benefits analysis, promoting the itinerary - to the identification of planning 
and design techniques to creating new routes - infrastructure plan, equipment for the routes themselves - able to provide answers to the increased demand for non systematic mobility of the recreation, tourism and reception kind. In this way new forms of tourism, when considered within a discussion on sustainability, often provide the answer for a new, unvoiced requirement for smooth and unsystematic mobility linked to leisure time which enables the surrounding areas to be experienced with new meaning. Planning for this type of mobility cannot therefore be limited to the infrastructure system, but should start out by identifying an area of interest for tourism and recreation with several resources, some of which to be visited, to specify the corridor inside which the infrastructure system of routes is to be set up. This area will be inevitably subject to greater environmental degradation (on the other hand more contained, under equal conditions, in the case of non motorised mobility) combining the requirements of tourism with those of the local communities.

As has come to light several times during research, the area is characterised by several natural linear features (rivers, etc.) and man-made features (disused railway lines, military roads, ancient historical itineraries, etc.) whose intrinsic features prove them to be the ideal place for building infrastructures for non motorised mobility in the area for the purpose of tourism as well.

The dual problem therefore arises, linked to the possibility of creating the infrastructure in the strict sense on the one hand, plus the effective possibility/opportunity of using the resources which characterise a particular area.

The effective possibility of using such resources is strongly influenced by buildings and their state of conservation, where real estate is concerned, as well as by the method of managing these same resources, to be looked on as setting up a network of public/private promoters which will have to be an integral part of the planning process.

"Smooth mobility" routes thus provide opportunities for recuperating the resources of the places they cross. "Smooth mobility" networks are aligned with the concept of sustainable tourism within the perspective of long-term preservation of environmental, social and cultural resources.

Faced with continuous globalisation and the consequent loss of the identity of local cultures, routes which are structured within local areas could provide a complementary and balanced contribution to economic development and the wellbeing of those who live and work in the communities which are visited.

Research has shown how planning itineraries for non mobilised motorisation for the purposes of tourism is economically sustainable in contexts where tourist activity is already well established or in those areas which can count on support due to large tourist hubs in the vicinity.

Routes envisaged in areas of high tourist attraction should be equipped bearing in mind just when it is advisable to support the presence of large user areas and thus be able to anticipate a series of welcoming and reception service structures. Equipment should be closely linked to the kind of tourism (farm holidays, wine and food trips, extreme and adventure tourism, etc.) to be encouraged in a given area. 
The "smooth mobility" network should thus be planned not as a single itinerary but as an interconnecting linkage of various routes, in order to expand the system for the area under consideration in time, on the basis of the expected influx of visitors using the network. The most significant problem is associated with day trippers entering the system which in some periods of the year reaches significant peaks, causing congestion on some of the main routes.

On the other hand planning routes in fragile areas should focus on specific aims with particular attention to estimating user selection, both by number and type, for the purpose of safeguarding areas which would otherwise be significantly compromised by human influx.

A functional classification of the system of routes seems to provide a suitable solution for forecasting the structural characteristics and levels of service on the basis of estimated suitable traffic volumes for a given network. So despite the fact that tourist activity is based on primarily economical assumptions, during the process of strategic decision-making to plan non-motorised mobility networks, it would be restrictive to consider only the economic sustainability of the project and look no further.

The social and environmental benefits deriving from the creation of a network of dedicated routes should be weighed and included in a careful economic analysis, taking all the interdisciplinary problems which are linked together into consideration.

A route, as such, should also be designed in relation to its function at local level and to the requirements connected with new forms of tourism.

Often new types of tourists select the social role of the routes available and move in groups. The different kinds of movement along the itinerary do not present a problem, where the possibility exists to make mixed use of the surface terrain.

The various tourist aspects for a "smooth mobility" route can be catalogued as follows:

- recreation aspect: the route attracts tourists - mainly groups of young people or families with children - in search of recreation and relaxation;

- educational aspect. The route is seen as a means for discovering and understanding the resources of the area it crosses. The kind of users who enjoy this educational function is mainly represented by school classes and organised groups which, thanks to the support of local entertainment, go on theme outings to improve their knowledge of the natural and cultural heritage of their surroundings;

- sport aspect: the route becomes a possibility for taking physical - but non competitive - exercise in the open and in complete safety;

- ecological and environmental aspect: the route provides the means of staying in contact with nature;

- the aspect of evaluating local traditions: the route provides the means for discovering the cultural aspects, wine, food and folklore which represent the identity of a local area.

These aspects could be turned into an offer and thus provide the chance of encountering local resources. 
Specialisation in the chosen itinerary - whether by theme or based on a local area - should be strongly influenced by the geo-morphological, economical and social characteristics of the local communities affected by the project.

In answer to the intentions of local administration, policies aimed at planning "smooth mobility" routes for local areas should bear in mind the following indications:

- identify the area of interest in social and/or tourism and recreation terms, characterised by abundant resources, some of which to be visited;

- decide on the corridor in which to create the infrastructure system of main and secondary routes, including connecting routes with the urban centres, the service structures already-existing in the area and with fundamental local units, first and foremost urban planning greenbelts;

- effectively plan and design the comprehensive network of routes, thus enabling the selected area to extend the system on the basis of network influx.

The fundamental reference criterion, when planning routes at local level, is the increase/reduction of the system as the years go by, on the basis of variations in effective user influx with time. The transport approach when designing routes is therefore unavoidable. This means making reference to specific parameters which have already been taken into consideration in the literature, such as for example: sizing the route on the basis of suitable service levels, the useful width of its cross-section, the overall size of functional furnishing and urban furnishing elements, the use of traffic-calming techniques also where non motorised users are concerned, etc.

The research carried out clearly shows that landscape is of fundamental importance when evaluating the local area through "smooth mobility" networks.

The landscape areas crossed are to be considered as the sum of the crosswise and lengthwise plans existing along the way and a determining factor for the route and its attractiveness. Landscaping should therefore be the guiding factor where planning is concerned. These landscapes should first and foremost conserve their role as a place of identity for the area and the local community to which they belong; the project must therefore also pay great attention to local cultural traditions, which are also to be considered as a fundamental part of the countryside system being crossed.

The main access points should be located in the urban areas, concentrating the high number of users in the areas with more human intervention, where the route will consist of wide, surfaced sections encouraging their dispersion, on the basis of the speed at which they move and the users wants, through an adequate selection of routes. The secondary access points should be located in a rural context.

It can thus be seen that project proposals for recovering or exploiting these linear aspects would involve much more extensive areas of the surface terrain for the infrastructure to be created, that is to say all the resources identified in a given area, made usable by creating the "smooth mobility" network, whether these be urban centres, isolated buildings, natural elements or landscapes. 
Of fundamental importance was the decision of just how to pitch the methodology by applying the theoretical results to the case study which concerned the embankment area along the River Adda in the stretch between the communes of Brivio and Trezzo sull'Adda.

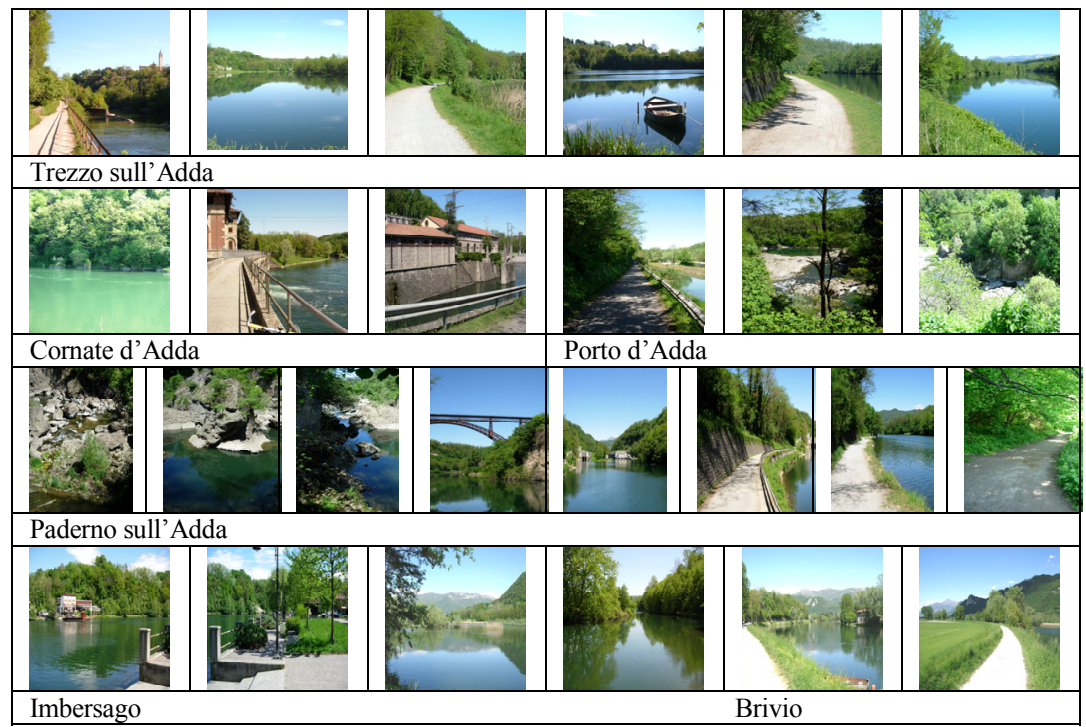

Figure 1: The waterfront of Adda River.

This environment is crossed by a natural linear feature (the River Adda) and a man-made one (the embankment along the River Adda); a system of this kind commonly found throughout Italy - offers an excellent opportunity for being used as the backbone for the "smooth mobility" infrastructure in the area by way of its intrinsic characteristics, such as: the linear nature of the route; the continuity of the courses; the presence of wide-radius bends; the average gentle slopes. In this way it is possible to observe how such a structuring component could be used in conjunction with the idea of a greenway, seen as a "system of routes dedicated to non motorised travel capable of connecting the population with the resources (natural, agricultural, landscape, historical and cultural) which the area has to offer, as well as with the urban settlement "living centres", both in the towns and in the rural areas" (Art. 2 of the National Greenway Association regulations). As has already been stressed the case study has focused its attention on the stretch of river running between Brivio and Trezzo sull'Adda. This stretch falls within the North Adda Park Area.

The area dealt with in this case study, although lacking the features of a marked tourism attraction, sees the Park as one of the major forces aware of all the potential this location has to offer, particularly where activities centred around the use of the embankment are concerned. This stretch of water is also the home of the "Leonardo Adda Ecomuseum": here visitors have the chance of 
admiring the landscape of Leonardo da Vinci, which includes the background to one of the most famous paintings by this great artist - who dwelt precisely in these places - such as "The virgin of the rocks" (and, perhaps the Mona Lisa").

This first aspect which came to light is linked with knowledge of the resources in the area under examination, in order to discover their true value. The choice of the surveys to be carried out is in itself a planning decision, as it outlines a choice of direction in the field of urban and local planning policies.

Among the surveys which have been completed in the research work, an important factor has been organising the local area, carrying out a morphological analysis and an analysis of the restrictions and the effective availability of the surface terrain (routes and adjacent connected areas), identifying the resources and accurately surveying and cataloguing all the existing routes.

The second aspect is directly linked to surveying the infrastructures already present in the area (corridor) under consideration and deriving from the previously mentioned surveys. In fact surveying operations in particular are determined by the specific aims involved; surveying the current state of the route has in fact provided in-depth knowledge of the area as this represents the basic tool for correct planning procedures. In the case of the River Adda, surveying operations required the existence of precise aims to be achieved, since an operation of this kind is difficult to standardise, precisely because it is strictly linked to the particular nature of the area concerned. The possibility of carrying out a survey by moving along the embankment of the River Adda with two ways of non motorised mobility to choose from (on foot or by bicycle) allowed those conducting the survey to put themselves in the ideal conditions to obtain a better understanding of the problems, advantages or disadvantages for travellers. The activity which occurs along a network for "smooth mobility" in fact provides opportunities for complex scenarios, with wide-ranging views which depend on the speed and the chosen means of transport, where the user forms an integral part of the landscape which he moves in.

Legal jurisdiction was fundamentally important in building the legislative reference scenario as a determining factor where planning decisions are concerned. An analysis of the restrictions and the availability of surface terrain shows, on the other hand, how the presence of an embankment represents a unique opportunity to be used for the case study area, lying as it does inside the boundaries of the North Adda Park which is de facto the governing authority.

Economic responsibility has proved to be fundamental when identifying the construction method for the "status matrixes" of the route and the competitiveness of the areas within which it is promoted.

The economic approach makes use of models featuring a series of auxiliary matrixes for the "status matrix" of the route.

Each individual matrix refers to different quantitative and qualitative components which contribute to provide the characteristics of the non-motorised mobility route. The status matrix, which represents a programming model for "smooth mobility" routes, has proved to be a tool which enables each of the various aspects to dialogue with the others, enabling them to entwine without neglecting any single component of the greenway product. 
Table 1: $\quad$ The status matrix.

\begin{tabular}{|c|c|c|c|c|c|c|}
\hline Reasons & $\begin{array}{c}\text { Functions/ } \\
\text { answers }\end{array}$ & Demand & Services & $\begin{array}{l}\text { Subjects } \\
\text { involved }\end{array}$ & $\begin{array}{c}\text { Type of } \\
\text { nfrastructure }\end{array}$ & $\begin{array}{c}\text { Landscape } \\
\text { structure }\end{array}$ \\
\hline $\begin{array}{l}\text { Recreation/ } \\
\text { relax }\end{array}$ & $\begin{array}{l}\text { Leisure } \\
\text { services }\end{array}$ & $\begin{array}{l}\text { Families } \\
\text { with } \\
\text { children, } \\
\text { disable } \\
\text { users, } \\
\text { tourists }\end{array}$ & $\begin{array}{c}\text { Recreational } \\
\text { areas, picnic } \\
\text { areas, park } \\
\text { benches, } \\
\text { fountains, } \\
\text { night } \\
\text { lighting } \\
\end{array}$ & $\begin{array}{c}\text { Local } \\
\text { administra- } \\
\text { tions, } \\
\text { associations, } \\
\text { voluntary } \\
\text { workers } \\
\text { groups } \\
\end{array}$ & Greenways & $\begin{array}{l}\text { Extra-urban } \\
\text { /urban }\end{array}$ \\
\hline $\begin{array}{l}\text { Leisure } \\
\text { activities }\end{array}$ & Sports & $\begin{array}{l}\text { Cycling } \\
\text { pedestrian } \\
\text { and } \\
\text { equestrian } \\
\text { tourism, } \\
\text { skaters, } \\
\text { rollers }\end{array}$ & $\begin{array}{c}\text { Bike racks, } \\
\text { drinking } \\
\text { trough and } \\
\text { horse stops, } \\
\text { bikes hire } \\
\text { and leisure } \\
\text { facilities }\end{array}$ & $\begin{array}{l}\text { Voluntary } \\
\text { workers } \\
\text { groups, } \\
\text { cycling and } \\
\text { equestrian } \\
\text { tourism } \\
\text { centres, } \\
\text { tourist } \\
\text { facilities } \\
\text { hirer } \\
\text { companies }\end{array}$ & $\begin{array}{c}\text { System of } \\
\text { trails } \\
\text { dedicated } \\
\text { with } \\
\text { different } \\
\text { levels of } \\
\text { difficulty }\end{array}$ & $\begin{array}{c}\text { Urban/ } \\
\text { extra-urban }\end{array}$ \\
\hline $\begin{array}{l}\text { Knowledge } \\
\text { protection }\end{array}$ & $\begin{array}{c}\text { Natural and } \\
\text { environmental } \\
\text { ambles }\end{array}$ & $\begin{array}{c}\text { Tourists } \\
\text { interesting } \\
\text { for the } \\
\text { environment } \\
\text { conservation }\end{array}$ & $\begin{array}{l}\text { Maps of the } \\
\text { paths, } \\
\text { references } \\
\text { about local } \\
\text { flora and } \\
\text { fauna }\end{array}$ & $\begin{array}{c}\text { Local } \\
\text { administra- } \\
\text { tions, } \\
\text { environmenta } \\
\text { associations, } \\
\text { C.A.I., corps } \\
\text { of forest } \\
\text { rangers } \\
\end{array}$ & $\begin{array}{c}\text { Greenways and } \\
\text { thematic ring } \\
\text { infrastructures }\end{array}$ & Extra-urban \\
\hline $\begin{array}{c}\text { Rediscovery } \\
\text { of rural } \\
\text { habitat }\end{array}$ & $\begin{array}{l}\text { Improvement } \\
\text { of traditions } \\
\text { and folklore }\end{array}$ & $\begin{array}{l}\text { Local and } \\
\text { rural } \\
\text { tourism }\end{array}$ & $\begin{array}{l}\text { Events, } \\
\text { market } \\
\text { places, } \\
\text { exhibition } \\
\text { markets }\end{array}$ & $\begin{array}{c}\text { Local } \\
\text { administra- } \\
\text { tions, } \\
\text { category } \\
\text { unions, } \\
\text { companies, } \\
\text { cultural } \\
\text { associations } \\
\end{array}$ & $\begin{array}{c}\text { Rural road } \\
\text { itinerary }\end{array}$ & Extra-urban \\
\hline $\begin{array}{l}\text { Historical/ } \\
\text { cultural }\end{array}$ & $\begin{array}{c}\text { Improvement } \\
\text { of historical } \\
\text { and cultural } \\
\text { resources }\end{array}$ & $\begin{array}{c}\text { Historical } \\
\text { tourism }\end{array}$ & $\begin{array}{l}\text { Information } \\
\text { panels, } \\
\text { guided tours }\end{array}$ & $\begin{array}{c}\text { Local } \\
\text { administra- } \\
\text { tions, } \\
\text { WWF, Lega } \\
\text { Ambiente, } \\
\text { Cultural } \\
\text { associations } \\
\text { Ecomuseum } \\
\text { cooperatives } \\
\text { of guides }\end{array}$ & Itinerary & $\begin{array}{c}\text { Urban/extra } \\
\text {-urban }\end{array}$ \\
\hline $\begin{array}{l}\text { Local } \\
\text { products }\end{array}$ & $\begin{array}{c}\text { Wine- } \\
\text { gastronomic } \\
\text { and } \\
\text { handicrafts } \\
\text { system }\end{array}$ & $\begin{array}{l}\text { Wine- } \\
\text { gastronomic } \\
\text { tourism }\end{array}$ & $\begin{array}{c}\text { Tour of } \\
\text { wine and } \\
\text { food grower } \\
\text { farm, local } \\
\text { markets }\end{array}$ & $\begin{array}{c}\text { Grower } \\
\text { farms, } \\
\text { restaurants, } \\
\text { hotels, } \\
\text { category } \\
\text { unions }\end{array}$ & Itinerary & $\begin{array}{l}\text { Extra-urban } \\
\text { /urban }\end{array}$ \\
\hline $\begin{array}{l}\text { Discovery/ } \\
\text { Guided } \\
\text { knowledge } \\
\text { to local } \\
\text { identities }\end{array}$ & Educational & $\begin{array}{l}\text { Students, } \\
\text { tourists } \\
\text { searching } \\
\text { for territory } \\
\text { resources }\end{array}$ & $\begin{array}{c}\text { Educational } \\
\text { and } \\
\text { expositive } \\
\text { mounting, } \\
\text { publications, } \\
\text { tours, } \\
\text { themed } \\
\text { trails }\end{array}$ & $\begin{array}{c}\text { Centres of } \\
\text { research, } \\
\text { cultural } \\
\text { centres, } \\
\text { institutions, } \\
\text { cooperatives } \\
\text { of guides, } \\
\text { local } \\
\text { authority }\end{array}$ & $\begin{array}{c}\text { System of } \\
\text { dedicated } \\
\text { trails }\end{array}$ & $\begin{array}{c}\text { Urban/ } \\
\text { extra-urban }\end{array}$ \\
\hline
\end{tabular}


With reference to the previous table, here following certain definitions:

- "Greenway": a system of routes dedicated to non motorised circulation able to connect population with the natural, agricultural, landscape and historic-cultural resources of territory and with the "life centres" of urban settlements, both in the cities and in rural areas.

- "Itinerary": signposted resources in a territory that aren't connected a structured way.

- "Trail": a simple/complex structured and equipped route for joining a physical way the territorial resources.

\section{Conclusions}

Research work has therefore demonstrated how individual aspects from the various sectors assist in considering the route as well integrated within its resident scenario.

The logic behind the development of sustainable tourism obliges us all to consider the individual elements which constitute the offer and the aspects of the area to be exploited, such as the non motorised mobility route, not solely as individual assets but in conjunction with the overall context of the area, the general offer and the promoters involved.

\section{References}

[1] Busi, R. \& Pezzagno, M., Greenway nell'infrastrutturazione del territorio, Le Strade n.4/2002, La Fiaccola: Milano, 2002.

[2] Busi, R., Elementi di urbanistica tecnica per una corretta pianificazione degli itinerari pedonali, Tecniche per la sicurezza in ambito urbano, Vol. 1, La protezione del pedone negli attraversamenti stradali, Egaf: Forlì, 2001.

[3] Forman, R.T.T., Ecology of greenways, D.S. Smith \& P.C. Hellemund editors: University of Minnesota, 1993.

[4] Fruin, J.J., Pedestrian Planning and Design, Metropolitan Association of Urban Designers and Environmental Planners: New York, 1971.

[5] Little, C.E., Greenways for America, The Jhons Hopkins University Press: Baltimore, 1990.

[6] Moore, R.L., Conflicts on multiple use trails: synthesis of the literature and the state of the practice, North Carolina state University, 1994.

[7] Pezzagno, M., Greenway nella pianificazione urbana e territoriale, Quaderno di Urbanistica tecnica n. 4, Sintesi: Brescia, 2002.

[8] Vias Verdes, Examples pour la promotion des voies vertes, Fundacion de los Ferrocerilles Espanoles, 2000.

[9] Voies Navigables de France (VNF), Définition d'une politique de voies navigables de France en matière de voies vertes sur le chemins de services dans une logique de grands itinéraires, Direction du développement de la voie d'eau patrimonie, 2000. 